\title{
IMPORTANCE OF THIN SEAMS RECONCILIATION IN A NEW COAL MINING PROSPECT AREA
}

\author{
1)Ali Achmad* \\ 1) Geologist \& Geotechnical Section PT Arutmin Indonesia Kintap Mine
}

Artikel masuk : 26-03-2021, Artikel diterima : 31-03-2021

\section{Kata kunci:}

Thin seams, Reserve, Pit shell, Reconciliation

\section{ABSTRACT}

Coal thin seams are often considered by companies as waste material. But these seams actually can be mined potentially and giving some profit if we manage it correctly. This paper will explain about how the importance to optimize of coal thin in the mining industry with the technical and economical perspectives starting with the iso-thickness polygon in the pit shell design (sign off) to coal reserves reconciliation completely. The Geologist must undertake monthly monitoring about the sum of coal thin seams and it is variance between actual versus model. The writer takes a study case from one on the area's PT Arutmin Indonesia concession. The location of the research area is situated in "Pit 4 Spessartine" with the coal thin seams succession from interval delta lower 2 - echo 1 lower. The Stratigraphy of the research area is a part of the Warukin Formation - Asem Asem Sub Basin. In this paper, the writer also reviewing the geological perspective so it can be known about the general parameters which controlled coal sedimentary deposited among them. We will disclose the paleo-peats distribution, paleo-base of their wetland or marsh and the last one is knowing about the water currents within the coal depositional environment. 


\section{INTRODUCTION}

The term of thin seams terminology is different in each coal mining companies. The mineable seams which is can be mined in PT Arutmin Indonesia Kintap Mine at least has minimum thickness 30 - 50 centimeter. The presence, distribution and geometry of thin seams can be seen at the cross section in geological model. These thin seams is controlled by the peat distribution and paleo-base of depositional environment. In General their were formed such in pinch out condition due to limitation of peat distribution. We often unrealized that thin seams can gives the more economical revenue and additional coal production in a pitshell design reserve until 5 $15 \%$ of reserve sum. The chance of valuable thin seam for example they usually below of basal seam in a pit design is known of thin seam that has the slighty interburden (figure 1). If we have an excellent mining plan properly thus we can take the additional revenue (USD \$) which is produced from thin seams reserves. Location of study area is situated in PT Arutmin Indonesia Kintap mine concession.

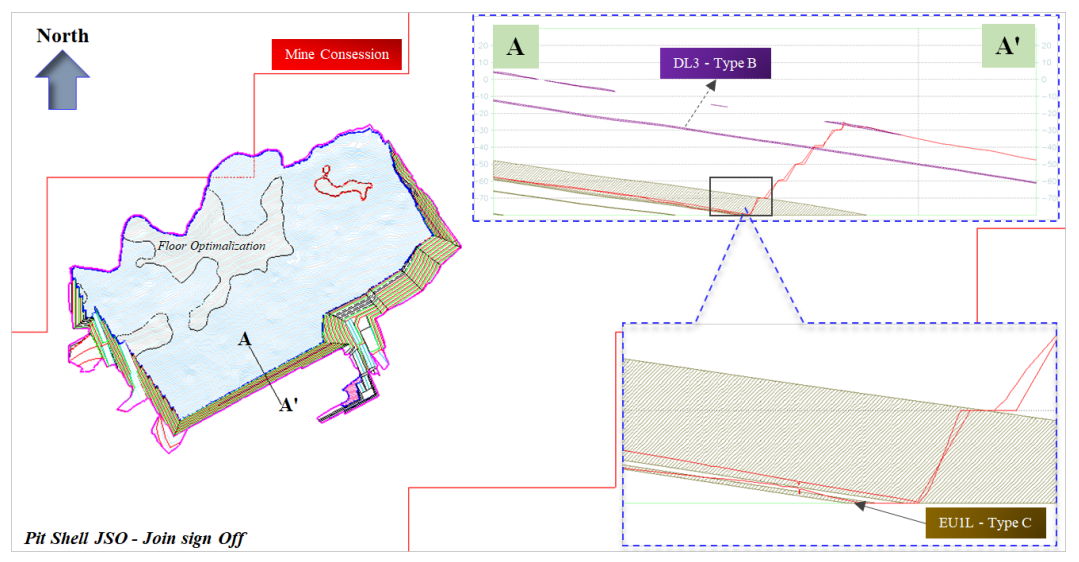

Figure 1. Pit shell JSO and thin seam opportunity to optimize it.

There are 5 (five) thin seams at Pit 4 Spessartine from the coal interval "Delta lower 2 upper to Echo upper 1 lower". They have various thickness and quality data starting from 0.1 to 1.3 meter and it has recorded in local stratigraphical column of Warukin formation in Kintap (figure 2). Most of them have a good total sulphur and medium ash. The differences of quality and quantity values are controlled by dynamical processes in the depositional environment during peat accumulation.

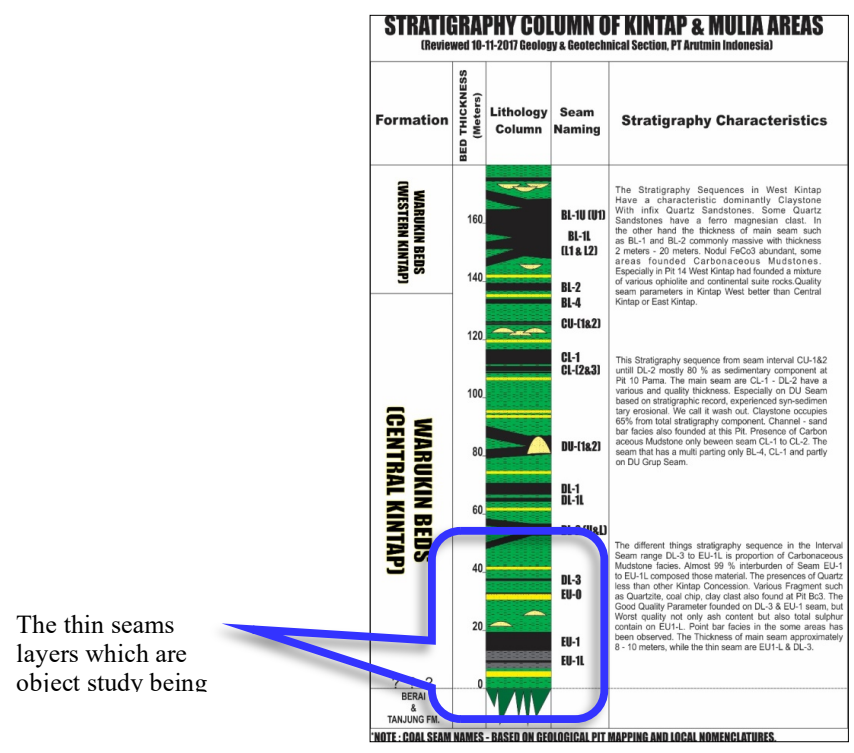


Figure 2. Local stratigraphy of Warukin Formation in Kintap Area. The object study at DL2UL - EU1L coal seams intervals.

The thin seams not only has a gain factors but also loss such as they so sensitive to descend of unit excavation productivity, ascending of ash content due to external impurities. On the other hand they are sensitive to be coal losses if don't treat according coal mining procedures operational standard. To avoid these loss factors, the geologist must delineate detailed information about distribution, thin seams variation, vertical interburden distance, iso-thickness and quality. Those informations that have mentioned before is useful to the define mine planning concept. Before and after the mine engineer would do the JSO (Join sign off) they must ensure and consider whole of geological information. It can be appropriated with mine planning production scheduling and equipment capacity. When the pit shell design has done, next steps are the mine geologist can calculate sum of thin seam reserve in pit shell boundary through iso-thickness method. Reviewing about economical and technical mine must be proposed and discussed to mine engineer and operation department. If the thin seams declare that is can be mined economically the geologist must be invited to the contractor related with join calculation, model reconciliation and defining mining target production that would be obtained from thin seams future. It is so Important because the thin seams delineation and reconciliation it is so useful to prepare a great operational excellent future and we can obtain maximum coal mining conservation.

\section{Main Purpose \& Objective}

In this paper will be explained about general geology setting, boundary of mineable coal seam delineation, coal thin seam reserves calculation, mine economical study, mine operational strategic and get a potential revenue that is obtained during mining operational. The output of this paper is giving a standard guidance to maximize coal thin seam recovery especially in a new prospect area.

\section{RESEARCH METHODOLOGY}

\section{Methodology \& Flow chart}

The methodology in our research comprises several stages. First, we must have a design pitshell join sign off (JSO) from mine engineer that had agreed both them. Second, We are try to identify and inventarization of thin seams which existed in the pit shell design through a geological cross sections and statistical model. Third, creating and delineating the iso-thickness every thin seams with minimum thickness $30-50 \mathrm{~cm}$. Fourth, calculating the reserves of thin seams that existed inside of pit shell boundary with minimum thickness that could be mined operationally. Fifth, joining and reconciling the thin seams inventarization with work partner (contractor). Indeed we must define the thin seams achievement in the future. A geologist must has a several planning points to do seam mapping in the pit shell design especially surround of thin seams polygon. Furthermore they also carry out model update quarterly and explaining about changing of thin seams polygon. The thin seams reserves must be updated monthly to know reserves status so we can control it. General workflow from these methodology can be seen as below (figure 3).

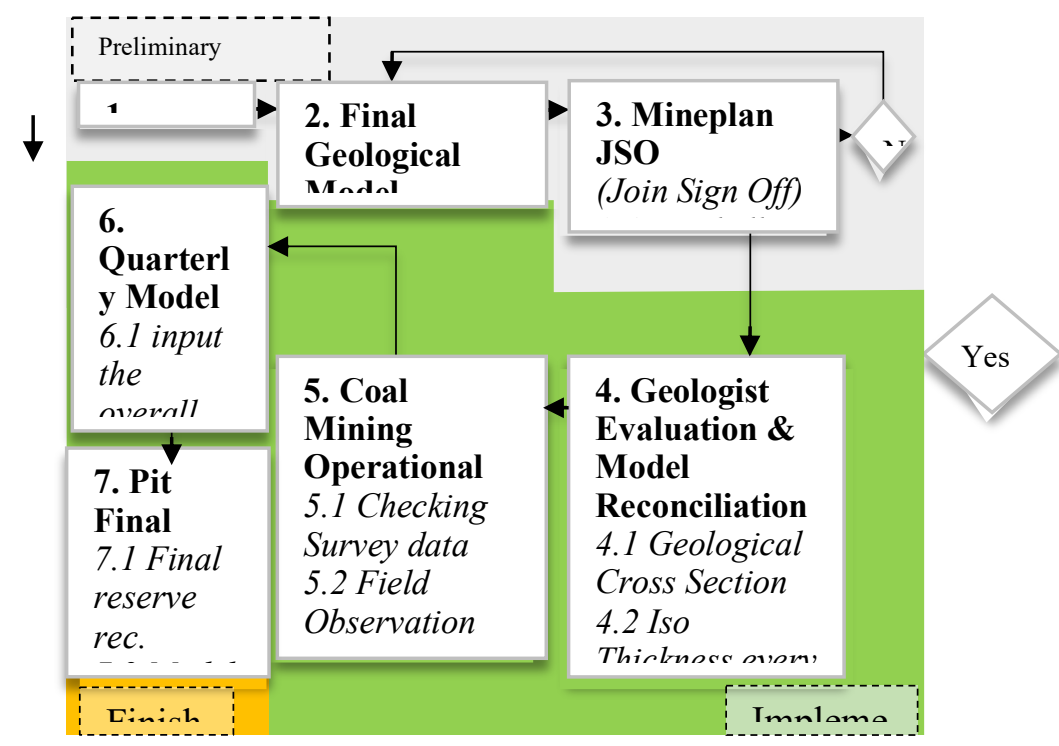


Figure 3. General work flow of thin seams coal conservation in a surface coal mining.

\section{RESULT \& DISCUSSION}

\section{General Geology}

Geological condition in study area is situated at Kintap regency, Tanah Laut Town, South Borneo Province. The geomorphic landform are consist of gently hills series and small valleys which is general pattern toward North - South. Lineament of the hills mostly have Northeast - Southwest trend. It parallel with regional strike of sedimentary rock. Stratigraphically, In the study area are composed by claystoned and inserted minor sandstone as channel and bar facies as deposited products. Pit 4 Sppessartine has $1,75 \mathrm{~km}$ long and 775 meters wide. Inside of this pit shell, we have 3 types of thin seams namely type $A, B \& C$ (figure 4). Type $A$ is signed appearance of splitting thin seams toward pit shell area. Type B they characterized in single seam which a limited distribution in the pit shell design. Type $C$ is the seams that lied underneath of basal seam target and have a chance to be mined due to vertical distance consideration. In the Pit 4 Spessartine we starting mining operational sequences from west at (blok 69) to the east (blok 82).

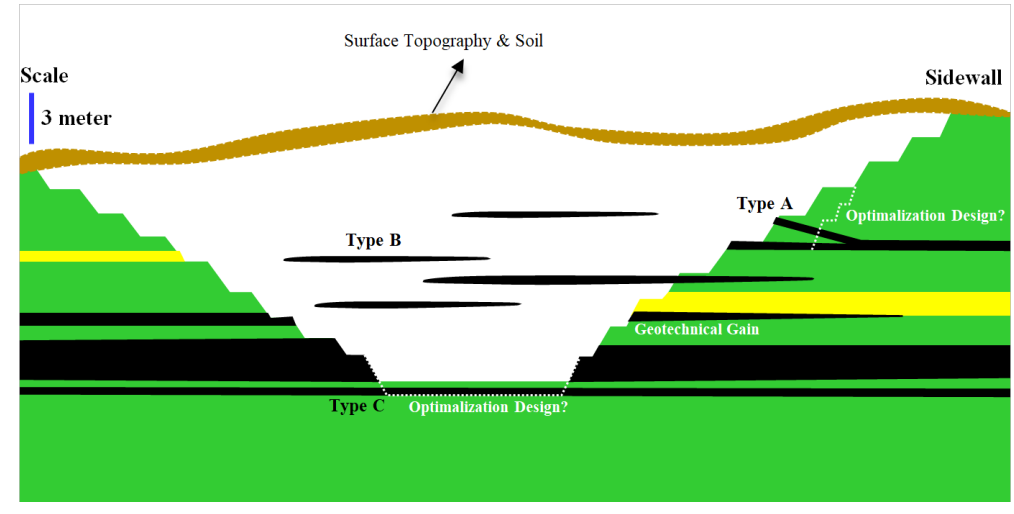

Figure 4. Types of thin seams geometry model in a pit shell design.

The continuity of 5 thin seams, only DL3 (delta lower 3 ) and EUO (echo upper 0) which is consistent of lateral seam distribution. In general the thin seams that located in Pit 4 Spessartine has "pinch" shaped. In some area they were cutted by erosional sandstone (wash out). Presencing of parting in their coal body usually found and ascend the quality ash.
It can descend the calorific values due to there are any contaminant in a stock pile area. The types of thin seams in Pit 4 Spessartine we capture through in some condition both DL3 and EU1L seam which existed underneath of main of basal seam condition (figure 5).

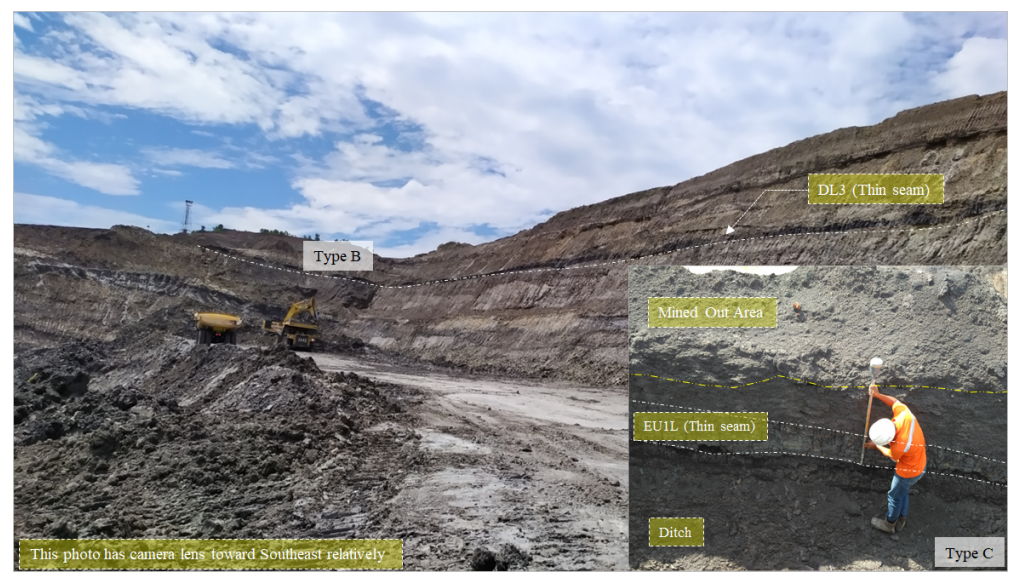

Figure 5. Field photograph of DL3 (type b) and EU1L lied under the basal seam (type c). 


\section{Stratigraphy Characteristic}

\subsection{DL2U \& DL2L Seam}

Distribution both seam DL2U and DL2L they as elemental from main seam DL2. Statistically they have thickness range from $0.2-0.85$ meter. These seams are distribute in the east (Blok 78 - 82) and west (B70 - 73) a part of pit shell area. They as seam splitting of DL2 (delta lower 2) as compound unit that has thickness reach up to 1.5 meter. Based on the initial reserves projection we could mined of these seams around 136,6 kTon and but based on survey data we got 70,6 kTon. These differences value due to some parameters such as model deviation and lose due to mining operational. The type of thin seam is type A. Coal recovery percentages both DL2U and DL2L are 68 and 61 $\%$. This category values included "fair" classification.

\subsection{DL3 Seam}

DL3 is the seam which is has greatest thickness and most consistent. They were distributed massively in every mining bloks area. Beginning from blok 69 to blok 82 they have a consistent thickness with range 0.5 meter - 1 meter. In the some area they are cutted by erosional sandstone (wash out) due to traction currents when syn-sedimentary depositional. DL3 have not splitting seam but they pinched at outside of pit shell area so we conclude that this thin seam is type B categorized. Based on the initial reserve projection we could mined of these seams around $628,8 \mathrm{kT}$ Ton and but based on survey data we got 504,8 kTon. These differences value due to several parameters such as model deviation, wash out and loses due to mining operational. Coal recovery percentages of DL3 is $84 \%$. This category values included "good" classification.

\subsection{EUO Seam}

One of the thin seams inside of Pit 4 Spessartine is seam EU0. They have thickness range from 0.2 0.94 meter. EUO distributed in west and east part of pit shell which has distribution pattern are Northeast
- Southwest directions. Beginning at blok 68 to blok 75 but they pinched out due to paleo-peat limit distribution. It might due to there was a high area that separated EUO's peat in the west and east area. We are classification that EUO seam include type B because they are still resemble with DL3 but only have a thickness and seam distribution differences. Based on the initial reserve projection we could mined of these seams around 148,7 kTon and but based on survey data we got 68,4 kTon. These differences value due to several parameters such as model deviation, wash out and losed due to mining operational. Coal recovery percentages of EU0 is 71 $\%$.This category values included "good" classification.

\subsection{EU1L Seam}

EU1L seam they were lied underneath of main target seam (EU1). We can define that this seam is categorized as type $C$. The interburden vertical distance with main seam around 0.5 meter - 1.8 meter which characterized presence of carbonaceous mudstone between EU1 - EU1L. This thin seam has a good opportunity is being mined. EU1L seam has dull luster that cutted by cleat so frequent. They are also worst quality seam whose total suphur reach $2 \%$. We are suspect that this seam is a part of lacustrine deposited. Based on the initial reserve projection we could mined of these seams around $110 \mathrm{kTon}$ and but based on survey data we got 42,9 kTon. These differences value due to several parameters such as model deviation, losed due to mining operational and we left that seam due to several consideration. The bad quality and difficulties during mining process due to stick of carbonaceous mudstone makes productivity equipment is descend. In the some area we left this seam due to lack of vertical thickness data so it rise uncertainties factor. Coal recovery percentages of EU1 just around $46 \%$. This category values included "poor" classification. The detail classification and calculation related thin seam reconciliation are explained in the table 1. 
Table 1. Coal seams inventarization in Pit 4 Spessartine.

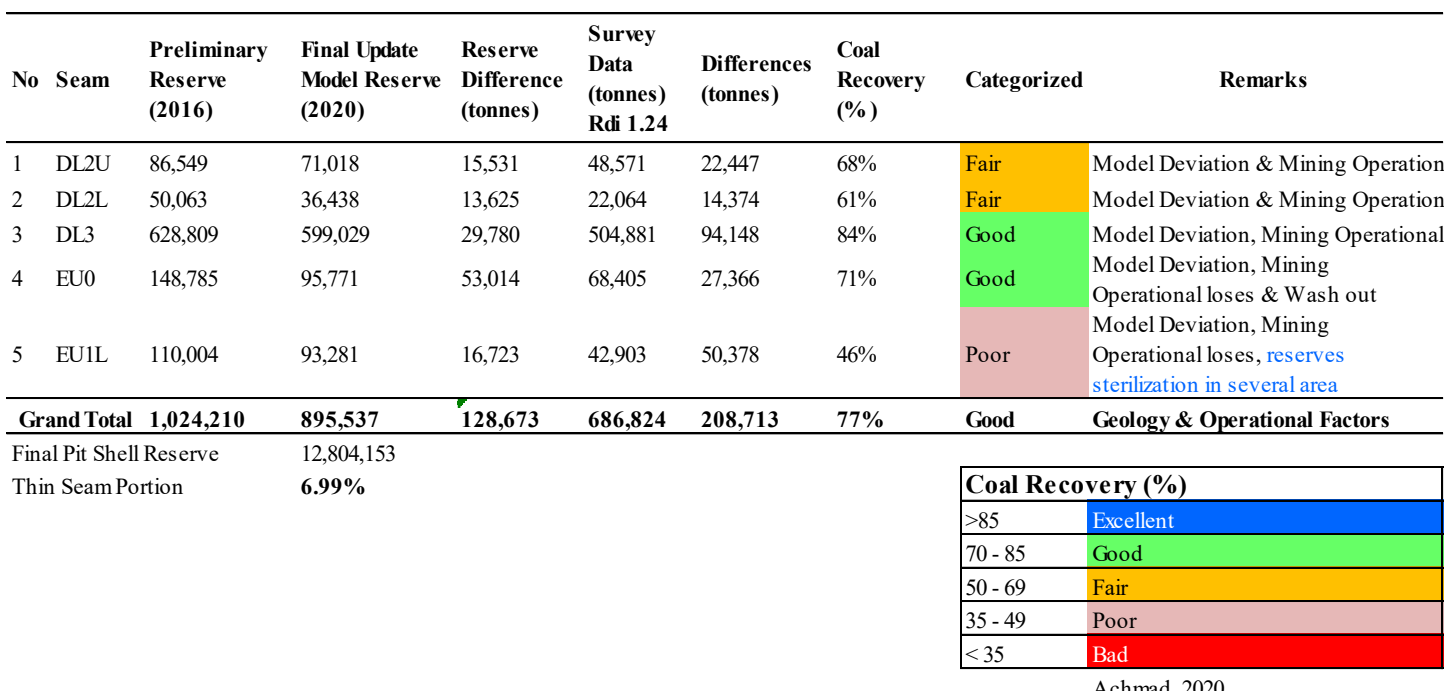

3

\section{. Thin Seam Reconciliation In a New Prospect Area}

The difference factors between geological model versus actual due to several factor. The matters that common occurred in coal mining industry is deviation model and actual due to limited of exploration data. Before the pit shell JSO would be implemented by mining operational, Geologist team must take place join reserves calculation related with thin seams inventarization. Model and reserve reconciliation should create a new minutes file then sign off both owner and contractor. Anticipating for the coal distribution variances we make a new reserves polygon buffer we call it as "buffer thin seam (BTS)" (figure 6). Usually we determinate the shift polygon of edge iso-thickness based on their geological condition. In this paper we define BTS is 25 meter from subcrop area and edge of seams distribution.

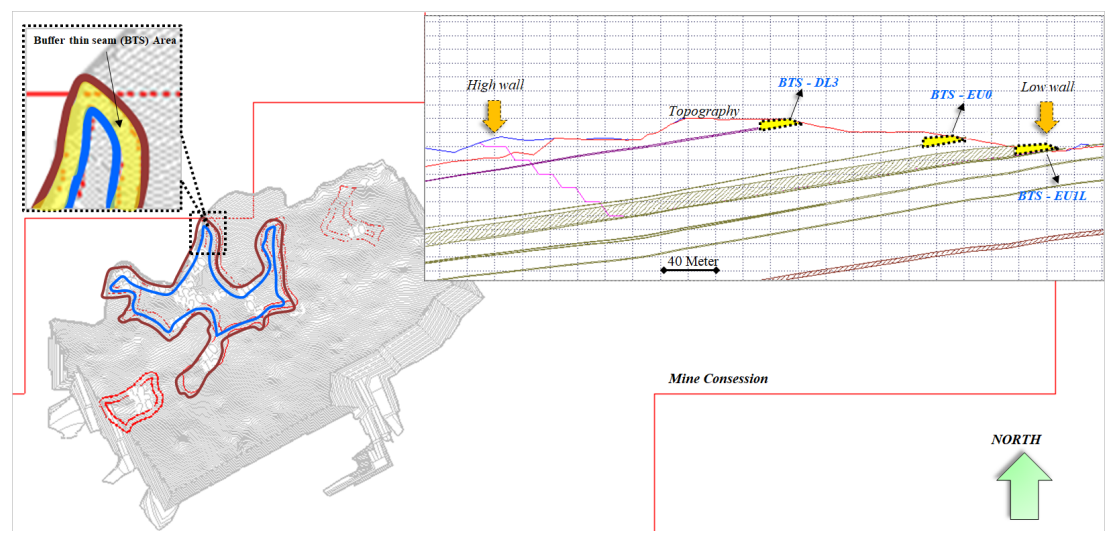

Figure 6. Buffer thin seam (BTS) area is a uncertainty or dynamical geological factors change and would be excluded in thin seam reconciliation.

This consideration based on radius influenced of measured resources where the space of among boreholes are 250 meter. This BTS area it means that both Arutmin and Contractor confess that is deviation area so we don't claim each others. During the mining process, both geologist and contractor must carry out their responsibilities. Geologist must define planing area to undertake geological mapping especially in BTS area. Detailed geological information must take place such as channel sampling and geological mapping. The point of observation (PoO) must follows the standard coal 
mining resources that be released by KCMI or BSN (badan standarisasi nasional). During implementation process and monitoring the Pit Geologist's contractor must report to the owner regarding variance factors or actual condition in the field when it condition showing a different with geological model. Then joining with Geologist's owner to delineate actual unmineable seam boundary. Geologist's Owner must do input that boundary to next quarterly model period. Updating reserve sum must be conveyed to the contractor when releasing a geological model quarterly. Sometimes loses survey data which is inside of mineable seam polygon it must be proven by PoO, both owner and contractor will investigate it (figure 7).

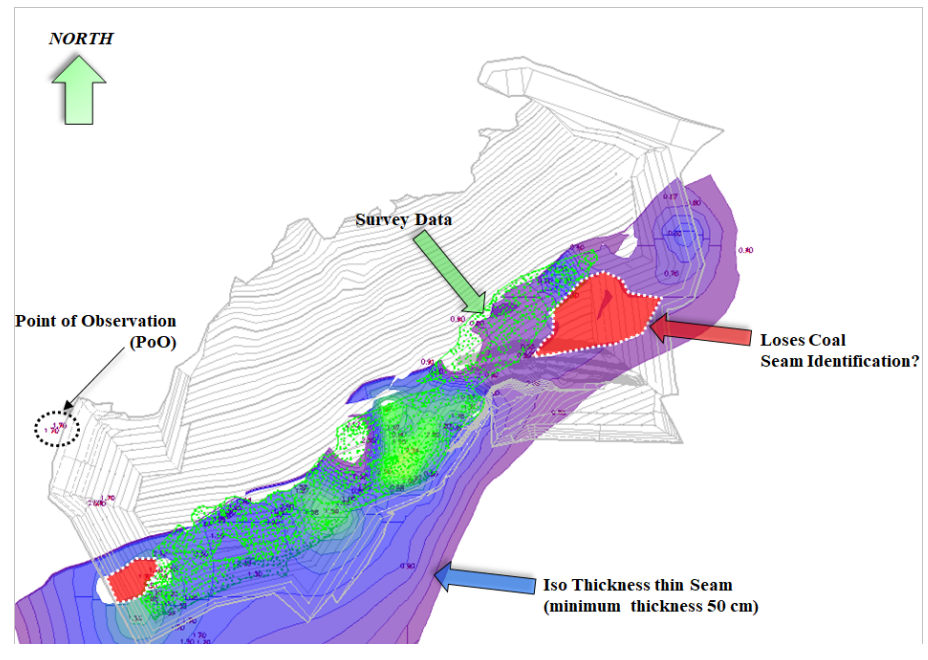

Figure 7. For example of loses thin seam identification due to there are no survey's data inside of mining operational design.

If it matter conclude as loses due to operational thus contractor would be pay back cash to owner. Through these procedures we have been proven that this method it so effiently to monitoring and optimize the thin seams because both owner and contractor would aware about thin seam mine conservation.
Buffer thin seams (BTS) inside of Pit shell JSO, we shift uncertainty area as far as 25 meter. Preliminary guidance to mining operational they are supported by mine Geologist the contour iso-thickness map and overlying with blok area to know distribution every thin seam which located inside of pit shell (figure 8).

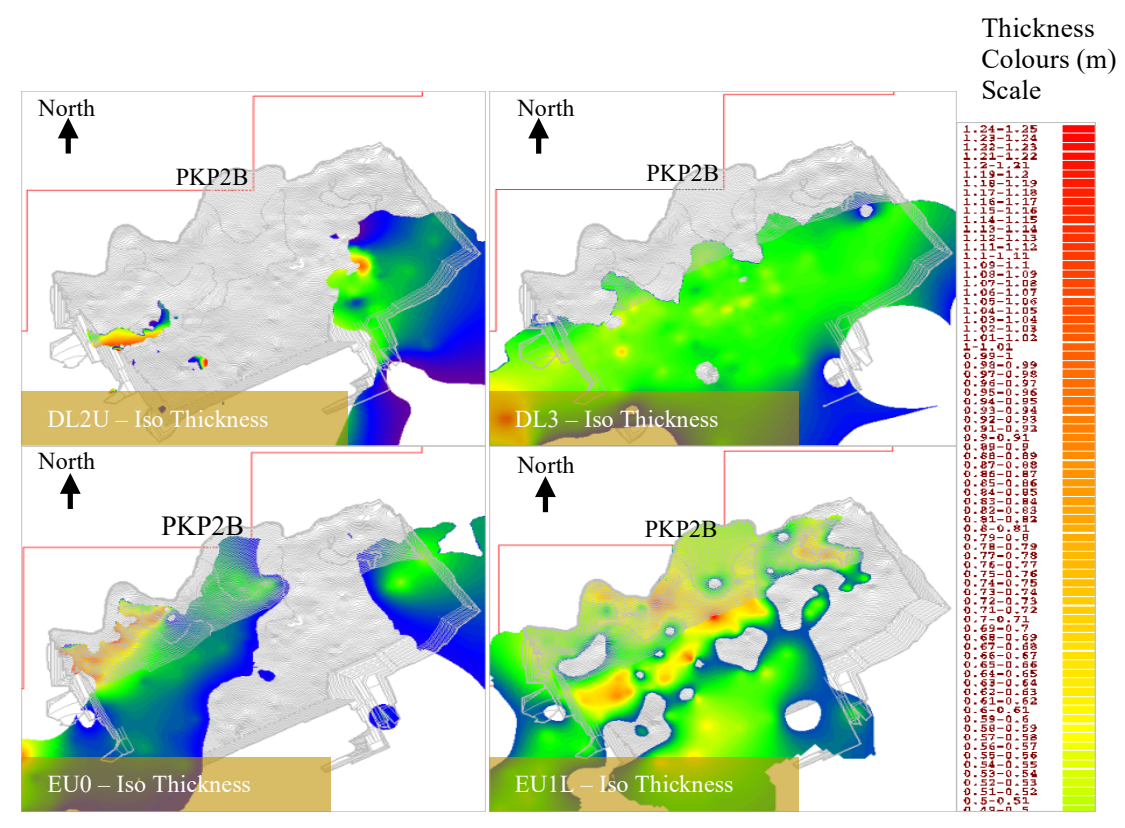


Figure 8. The iso-thickness distribution contours on starting DL2U to EU1L inside of Pit 4 Spessartine.

\section{CONCLUSION}

In this paper, we have been concluded several keys consideration as follows ;

1. Geological consideration and thin seams reviewing it is so important before we would open a new prospect area or pit design to do a plan regarding mining operational in the future.

2. There are several types of thin seams geometries in Pit 4 Spessartine and we classified it into 3 types $(A, B \& C)$. Type $A$ is $a$ thin seam which is showed splitting when they are enter the pit design. Type B is the thin seam which is distributed inside of pit shell consistently. A usual condition they are pinch out or are cutted by erosional sandstone. Type $C$ is the thin seam that underlined beneath basal seam. Based on economical and technical analysis, this type thin seam it could be optimalized.

3. There are several parameters that used in coal thin seam reconciliation. The writer give a sample as "Buffer thin seam" (BTS). This BTS area is common showed deviation between model versus area such as in subcrop area and lateral seam distribution (on strike).

4. There are 5 (five) thin seams inside of Pit 4 Spessartine with interval seam starting from
DL2U to EU1L. Based on model calculation and survey's data measurement we are categorize those seams "poor" to "good" coal recovery.

\section{ACKNOWLEDGEMENT}

The author convey thanks you for PT Arutmin Indonesia Kintap Mine Management because supporting me to write this paper. Thank you for Mine engineer and survey section as my colleague in Engineering department whom are support me a lot of data to finalization this paper. This paper has a purpose as preliminary guidance for geologist when overcoming a new prospect areas. Reserves conservation must optimalize coal reserve thoroughly. It might this paper gives usefulness to a reader everyone who is read it.

\section{REFERENCES}

Achmad, A. (2017): Optimalisasi cadangan Batubara di luar Pit sebagai upaya dalam peningkatan angka produksi, Prosiding TPT XXVI 2017, PERHAPI, Balikpapan.

Operational Standard Procedure (2018) : Coal thin seam recovery and optimalization in mining operational area, PT Arutmin Indonesia, Kintap. 